\title{
Pengembangan metode pembelajaran halaqah berbasis etnomatematika untuk memahamkan penyelesaian masalah transportasi kelas program linear
}

\author{
Hartono $^{1 * \text { iD , Wandra Irvandi }}{ }^{1}$ \\ ${ }^{1}$ Program Studi Pendidikan Matematika, IKIP PGRI Pontianak, Pontianak, Indonesia \\ * Corresponding Author. E-mail: andra.hartono@gmail.com
}

\begin{tabular}{|c|c|}
\hline ARTICLE INFO & ABSTRACT \\
\hline $\begin{array}{l}\text { Keywords: } \\
\text { Metode pembelajaran } \\
\text { halaqah, } \\
\text { Etnomatematika, } \\
\text { Pembelajaran program } \\
\text { linear, } \\
\text { Halaqoh learning method, } \\
\text { Ethnomathematics, } \\
\text { Linear program learning. }\end{array}$ & $\begin{array}{l}\text { Tujuan penelitian ini adalah untuk menghasilkan metode pembelajaran halaqah berbasis etno- } \\
\text { matematika pada kelas program linear untuk membantu mahasiswa memahami penyelesaian } \\
\text { masalah transportasi. Penelitian dan pengembangan ini terdiri dari tahap define, design, dan } \\
\text { develop. Instrumen penelitian yang digunakan adalah lembar validasi untuk menilai kevalidan, } \\
\text { angket untuk menilai kepraktisan, dan tes hasil belajar untuk menilai keefektifan metode pem- } \\
\text { belajaran halaqah berbasis etnomatematika. Penelitian menghasilkan metode pembelajaran } \\
\text { yang terdiri dari empat tahapan. Tahap pertama yaitu pemilihan kompetensi dan materi ber- } \\
\text { basis etnomatematika, dan kompetensi terkait pemahaman penyelesaian masalah transportasi } \\
\text { dengan konteks berupa pembiayaan transportasi pembuatan baju tradisional Kopa etnis Dayak } \\
\text { Kualant. Tahap kedua, pembentukan halaqah yaitu dengan posisi melingkar, kemudian pemi- } \\
\text { lihan mahasiswa yang berkemampuan tinggi sebagai pembimbing, dilanjutkan ta'aruf dengan } \\
\text { penuh keakraban. Tahap ketiga, kegiatan pembelajaran yaitu pemahaman materi yang terdiri } \\
\text { dari pembukaan, landasan ide pokok materi transportasi. Tahap keempat, kegiatan silaturahmi } \\
\text { di luar pembelajaran sekaligus mengevaluasi dan mempererat persaudaraan mahasiswa seba- } \\
\text { gai teman diskusi. Berdasarkan penilaian kevalidan, kepraktisan, dan keefektifan disimpulkan } \\
\text { bahwa metode pembelajaran halaqah berbasis etnomatematika yang dikembangkan layak di- } \\
\text { gunakan dan dapat dilanjutkan ke uji coba dalam skala besar. }\end{array}$ \\
\hline
\end{tabular}

Scan me:

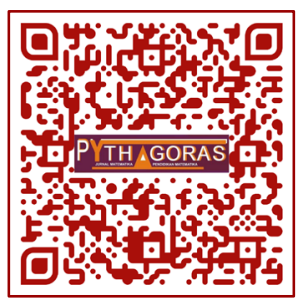

The purpose of this study was to produce an ethnomathematics-based halaqah learning method in a linear program course to help students understand solving transportation problems. This research and development consisted of the define, design, and development stages. The research instrument used was a validation sheet to assess the validity, a questionnaire to assess practicality, and a test to assess the effectiveness of the ethnomathematics-based halaqah learning method. The research resulted in a learning method consisting of four stages. The first stage was selecting ethnomathematics-based competencies and materials and competencies related to understanding transportation problem-solving in the context of financing the production of the traditional clothing of Kopa Dayak Kualant ethnic. The second stage, the formation of the halaqah, namely in a circular position, then selects highly capable students as guides, followed by ta'aruf with full intimacy. The third stage was learning activities, namely understanding the material consisting of opening, the basic idea of transportation material. The fourth stage was activities outside of learning and evaluating and strengthening students' brotherhood as discussion partners. Based on the assessment of the validity, practicality, and effectiveness, it could be concluded that the ethnomathematics-based halaqah learning method developed was suitable for use and could be continued in large-scale trials.

This is an open access article under the CC-BY-SA license

\section{How to Cite:}

Hartono, H., \& Irvandi, W. (2020). Pengembangan metode pembelajaran halaqah berbasis etnomatematika untuk memahamkan penyelesaian masalah transportasi kelas program linear. Pythagoras: Jurnal Pendidikan Matematika, 15(2), $216-226$. https://doi.org/10.21831/pg.v15i2.36432 


\section{PENDAHULUAN}

Pembelajaran matematika dalam beberapa kasus menjadi hal yang paling dihindari oleh peserta didik. Hal tersebut ditunjukkan dengan adanya peserta didik dalam setiap jenjang yang mengalami kesulitan belajar matematika. Kumalasari dan Sugiman (2015) memaparkan kesulitan belajar matematika yang dialami oleh mahasiswa pendidikan matematika ada 12 jenis, yaitu: kesulitan mengingat fakta, kesulitan mengingat konsep, kesulitan memahami fakta, kesulitan memahami konsep, kesulitan menerapkan konsep, kesulitan menerapkan prosedur, kesulitan menganalisis prosedur, kesulitan mengevaluasi konsep, kesulitan mengevaluasi prosedur, kesulitan mengomunikasikan metakognitif, kesulitan meneliti fakta, dan kesulitan meneliti prosedur. Walaupun setiap orang mengalami jenis kesulitan yang berbeda-beda, tetap saja kesulitan tersebut haruslah dicarikan solusinya untuk meminimalisir terjadinya kesalahan belajar.

Menurut Abdurrahman (Tanjungsari et al., 2012), kesulitan belajar adalah ketidakmampuan peserta didik untuk belajar sebagaimana mestinya. Ketidakmampuan yang dialami oleh peserta didik dapat dideteksi melalui kesalahan belajarnya. Kesalahan belajar yang dilakukan oleh mahasiswa pendidikan matematika IKIP PGRI Pontianak sebagaimana dipaparkan oleh Oktaviana (2018) cenderung pada prosedur pengerjaan, yaitu kesalahan dalam memahami soal, pertanyaan dari soal, hingga menghasilkan jawaban akhir dari soal. Salah satu mata kuliah yang harus ditempuh mahasiswa pendidikan matematika IKIP PGRI Pontianak adalah program linear. Salah satu topik pada mata kuliah program linear tersebut adalah prosedur penyelesaian masalah transportasi. Hasil belajar mahasiswa pada mata kuliah program linear semester genap tahun ajaran 2018/2019 menunjukkan bahwa dari 42 mahasiswa, hanya 10 orang yang mendapat nilai di atas 60 . Berdasarkan analisis jawaban mahasiswa pada soal ujian akhir semester program linear sekitar $76 \%$ mahasiswa tidak dapat melakukan prosedur penyelesaian masalah transportasi terutama dalam uji optimalisasi dan revisi tabel.

Hasil belajar mahasiswa program linear dapat dipengaruhi oleh aktivitas belajar mahasiswa (Muchtadi et al., 2017). Aktivitas belajar mahasiswa dapat diarahkan sesuai dengan model, strategi, atau pendekatan pembelajaran yang digunakan selama perkuliahan. Ketepatan dalam penggunaan metode pembelajaran menjadi suatu alternatif yang lebih menyentuh pada aktivitas belajar mahasiswa. Octaria dan Puspasari (2018) menyatakan bahwa pembelajaran untuk mata kuliah program linear perlu adanya variasi, karena pembelajaran selama ini cenderung sifatnya konvensional. Dalam dunia dakwah Islam, ada suatu metode pembelajaran ilmu Islam yang disebut dengan halaqah (Soleh et al., 2018). Metode pembelajaran ini umumnya ditandai dengan pembelajaran dengan kelompokkelompok kecil yang beranggotakan lebih dari dua orang dengan satu orang dianggap sebagai pembimbing (Junaidi, 2016). Halaqah berasal dari bahasa arab yang kata dasarnya liqa' yang artinya pertemuan, sedangkan halaqah menurut Munawwir (1997) secara bahasa artinya adalah kalung, lingkaran, atau kumpulan orang yang duduk berbentuk lingkaran. Pembelajaran dengan metode halaqah pertama kali dikembangkan dalam pelaksanaan pendidikan agama Islam (Umam et al., 2020). Metode pembelajaran ini menekankan pada pendekatan secara personal yang mana tiap-tiap pembimbing bertanggung jawab terhadap pemahaman materi yang disampaikan (Dalimunthe, 2019). Oleh karena itu, dalam rangka memahamkan prosedur penyelesaian masalah transportasi pada mata kuliah program linear dapat mengadopsi metode pembelajaran tersebut.

Menurut Nisar (Muslimin, 2016), dalam metode halaqah setiap kelompok didampingi oleh murobbi yang merupakan senior dari peserta didik sebagai pebelajar, pemahaman yang ditanamkan secara santai dengan formasi duduk melingkar. Pendamping atau disebut murobbi dipilih dari senior yang paham akan materi yang akan diajarkan. Pembelajaran menggunakan metode halaqah memberikan suasana yang penuh kedekatan antara peserta didik dengan murobbi, sehingga kesulitan atau kesalahan belajar dapat diselesaikan bersama-sama. Halaqah telah digunakan dalam pembelajaran bahasa yang memberikan peningkatan kemampuan menulis teks eksplanasi yang cukup signifikan (Amirudin et al., 2018), sehingga metode halaqah ini perlu juga diadopsi untuk dikembangkan dalam pembelajaran matematika. Metode halaqah memberikan suasana pembelajaran yang menyenangkan dalam proses transfer materi dengan mengedepankan rasa kekeluargaan (Mujizatullah, 2018). Suasana menyenangkan dapat dilakukan melalui penggunaan konteks kehidupan sehari-hari (Sulianto, 2008). Konteks yang dimaksud adalah objek belajar yang berada di sekitar mahasiswa. Objek belajar tersebut berupa benda atau aktivitas mahasiswa yang memuat konsep matematika.

Belajar matematika tidak hanya membutuhkan metode pembelajaran, diperlukan juga adanya suatu media atau objek yang dapat dijadikan sumber atau sarana belajar. Belajar dengan memanfaatkan lingkungan sekitar dapat meningkatkan pemahaman terhadap materi matematika (Agustina, 2016). Lingkungan belajar dapat berupa 
unsur budaya dan perwujudannya (Putri, 2017). Konsep matematika yang digunakan oleh kelompok masyarakat terhadap suatu benda atau aktivitas baik dalam budaya maupun kehidupan sehari-hari dikategorikan sebagai etnomatematika oleh Gerdes (Haran et al., 2019). Matematika yang ada dalam unsur budaya dan perwujudannya disebut juga etnomatematika (Abi, 2017), sehingga pembelajaran matematika dapat menggunakannya sebagai konteks dalam memahamkan konsep atau prosedur matematis kepada peserta didik. Unsur budaya dan perwujudannya dapat menjadi konteks pembelajaran seperti yang dipaparkan oleh Hartono dan Saputro (2019). Etnomatematika adalah perwujudan secara lengkap dan dinamis yang menggambarkan budaya penggunaan matematika dan aplikasinya (Hartoyo, 2012). Matematika pada dasarnya menjadi bagian tak terpisahkan dengan kebudayaan dan perwujudannya, contohnya konsep geometri rumit yang diterapkan masyarakat Dayak pada motifmotif anyaman topi (Hartoyo, 2012), konsep bangun geometri persegi panjang di balik kerajinan anyaman Bali (Puspadewi \& Putra, 2014), dan konsep geometri dan teknik membilang pada kesenian rebana (Putri, 2017). Etnomatematika dalam pembelajaran matematika sudah banyak dikembangkan, misalnya permainan tebak-tebak buah manggis sebagai inovasi pembelajaran matematika yang berbasis etnomatematika (Hariastuti, 2017), pengembangan lembar kerja siswa berbasis etnomatematika yang membangun pemahaman konsep (Hasanah et al., 2019), dan pengembangan modul pembelajaran matematika berbasis etnomatematika menggunakan metode inkuiri (Mardiah et al., 2018). Namun pengembangan pembelajaran etnomatematika yang dikombinasikan dengan metode halaqah belum ditemukan.

Berdasarkan latar belakang dan kajian teori yang telah dikemukakan, maka perlu adanya pengembangan metode pembelajaran pada mata kuliah program linear yang sebelumnya belum pernah menggunakan metode halaqah berbasis etnomatematika. Sari et al. (2017) merekomendasikan bahwa perlu adanya inovasi untuk mengatasi hambatan belajar mahasiswa pada mata kuliah program linear, dan pengembangan metode pembelajaran yang dilakukan pada penelitian ini diharapkan menjadi solusi atas permasalahan tersebut. Dengan demikian, tujuan penelitian ini adalah untuk menghasilkan metode pembelajaran halaqah berbasis etnomatematika untuk membantu mahasiswa memahami penyelesaian masalah transportasi pada mata kuliah program linear yang valid, praktis, dan efektif.

\section{METODE}

Metode penelitian yang digunakan adalah penelitian dan pengembangan. Penelitian dan pengembangan ini bertujuan untuk menghasilkan metode pembelajaran halaqah berbasis etnomatematika dalam memahamkan penyelesaian masalah transportasi pada mata kuliah program linear. Penelitian ini menggunakan model pengembangan $4 \mathrm{D}$ yang terdiri dari empat tahap, yaitu pendefinisian (define), perancangan (design), pengembangan (develop), dan penyebar luasan (disseminate) (Thiagarajan et al., 1974). Pelaksanaan penelitian pengembangan metode pembelajaran ini dibatasi sampai pada tahap pengembangan (develop) bagian pertama yaitu validasi prototype metode pembelajaran, uji kepraktisan, dan uji keefektifan.

\section{Tahap Pendefinisian (Define)}

Pada tahap ini ditetapkan dan didefinisikan kebutuhan perkuliahan program linear dengan menganalisis tujuan mata kuliah program linear dan batasan materinya berdasarkan kurikulum di Program Studi Pendidikan Matematika IKIP PGRI Pontianak. Kegiatan yang dilakukan adalah analisis awal-akhir, analisis mahasiswa, analisis konsep, analisis tugas, dan analisis spesifikasi tujuan perkuliahan. Kegiatan yang dilakukan pada tahap analisis awal-akhir adalah menentukan masalah dasar yang diperlukan untuk mengembangkan metode pembelajaran. Hal ini dilakukan dengan menelaah kurikulum dan teori belajar yang relevan, sehingga diperoleh deskripsi model pembelajaran yang dianggap sesuai. Pada penelitian ini, metode pembelajaran yang dikembangkan untuk mata kuliah program linear terbatas pada topik penyelesaian masalah transportasi. Kegiatan selanjutnya adalah analisis mahasiswa yang merupakan telaah karakteristik mahasiswa yang sesuai dengan rancangan pengembangan metode pembelajaran. Analisis konsep adalah suatu kegiatan mengidentifikasi, merinci, dan menyusun secara sistematis materi dan sumber bacaan perkuliahan yang relevan untuk dibentuk menjadi metode pembelajaran, berdasarkan analisis awalakhir. Pada analisis tugas, kegiatan yang dilakukan adalah mengidentifikasi keterampilan apa saja yang menjadi poin utama untuk melaksanakan perkuliahan program linear. Dari analisis tugas, keterampilan utama yang sudah teridentifikasi dikaji keterampilan tambahan yang mungkin dibutuhkan. Tahap terakhir pada pendefinisian adalah menentukan spesifikasi tujuan perkuliahan. Dalam kegiatan ini dilakukan konversi standar kompetensi dan kompetensi dasar dari analisis tugas dan analisis konsep menjadi tujuan perkuliahan. 


\section{Tahap Perancangan (Design)}

Tahap ini merupakan tahap awal dari perancangan metode pembelajaran yang akan digunakan dalam mata kuliah program linear. Selain itu juga disusun instrumen validasi, angket respon pembelajaran, dan tes masalah transportasi.

\section{Tahap pengembangan (Develop)}

Dalam tahap ini, terdiri dari dua kegiatan yaitu validasi desain metode pembelajaran dan uji coba produk. Prototype metode pembelajaran yang telah dirancang selanjutnya divalidasi oleh tiga orang validator sehingga diperoleh masukan, evaluasi, dan revisi terhadap metode pembelajaran yang telah dirancang. Tahap ini merupakan tahap akhir dari pengembangan metode pembelajaran pada semester genap. Selanjutnya metode pembelajaran yang telah direvisi berdasarkan masukan dari para validator akan diujicobakan pada perkuliahan di semester ganjil.

Metode pembelajaran halaqah adalah metode pembelajaran dengan penyampaian materi dengan membentuk kelompok kecil dengan format pembelajaran duduk melingkar dengan satu orang pembimbing di masingmasing kelompok. Etnomatematika adalah konsep matematika yang ada dalam budaya atau kebiasaan dalam kehidupan bermasyarakat, dalam hal ini konteks masalah yang digunakan adalah pembiayaan transportasi pembuatan baju Kopa etnis Dayak Kualant. Masalah transportasi adalah konsep penyelesaian dalam masalah transportasi barang agar biaya yang dihabiskan menjadi efisien. Penelitian ini melibatkan tiga orang dosen pendidikan matematika sebagai validator, dengan masing-masing konsentrasi pada pengajaran matematika, pengembangan perangkat pembelajaran matematika, dan etnomatematika. Subjek uji coba adalah mahasiswa program studi pendidikan matematika yang sedang menempuh mata kuliah program linear tepatnya di semester IV sebanyak 31 orang.

Kevalidan metode pembelajaran halaqah berbasis etnomatematika untuk memahamkan mahasiswa dalam menyelesaikan masalah transportasi dinilai oleh ahli menggunakan angket validasi. Penilaian terdiri dari aspekaspek antara lain: dasar teori metode pembelajaran, analisis kebutuhan metode pembelajaran, tujuan dikembangkannya metode pembelajaran, penjelasan metode pembelajaran, langkah metode pembelajaran, kelengkapan pendukung metode pembelajaran, evaluasi dan penilaian dalam metode pembelajaran, serta target capaian metode pembelajaran. Revisi akan didapat dari data kualitatif berupa masukan dan saran dari ahli. Sedangkan data kuantitatif digunakan untuk mengolah data dari angket yang menggunakan skala Likert yang terdiri atas lima kriteria yang akan dianalisis dengan rumus Hasil Rating (HR) yang digunakan oleh Riduwan (Yudhaskara, 2016, p. 893), yaitu sebagai berikut.

$$
H R=\frac{\sum \text { Skor validator }}{\sum \text { Skor tertinggi }} \times 100 \%
$$

Selanjutnya, kategori tingkat kevalidan dan interpretasinya disajikan pada Tabel 1. Kategori kevalidan pada penelitian ini ditentukan dengan kriteria minimal "Cukup Valid", maka metode pembelajaran ini sudah dapat digunakan dengan sedikit revisi.

Tabel 1. Kategori kevalidan produk

\begin{tabular}{lccl}
\hline Penilaian & Skala nilai & Hasil rating $(\%)$ & Keterangan \\
\hline Sangat valid & 5 & $86-100$ & Tidak revisi \\
Valid & 4 & $66-85$ & Sedikit revisi \\
Cukup valid & 3 & $51-65$ & Sedikit revisi \\
Tidak valid & 2 & $36-50$ & Revisi \\
Sangat tidak valid & 1 & $20-35$ & Revisi \\
\hline
\end{tabular}

Kepraktisan model pembelajaran yang dikembangkan didapat dari hasil angket respon mahasiswa dan dosen dengan menggunakan skala Likert. Dengan menggunakan rumus yang sama dengan penilaian kevalidan produk, maka Hasil Rating $(H R)$ untuk menilai kepraktisan produk yang dikembangkan didapat melalui rumus sebagai berikut.

$$
H R=\frac{\sum \text { Skor penilai }}{\sum \text { Skor tertinggi angket }} \times 100 \%
$$

Selanjutnya, kategori tingkat kepraktisan dan interpretasinya diukur berdasarkan Tabel 2. Nilai kepraktisan pada penelitian ini ditentukan dengan kriteria minimal "Cukup Praktis", maka bahan ajar sudah dapat dimanfaatkan sebagai media pembelajaran dengan sedikit revisi. 
PYTHAGORAS: Jurnal Pendidikan Matematika, 15 (2), 2020 - 220

Hartono, Wandra Irvandi

Tabel 2. Kategori kepraktisan produk

\begin{tabular}{lccl}
\hline Penilaian & Skala nilai & Hasil rating $(\%)$ & Keterangan \\
\hline Sangat praktis & 5 & $86-100$ & Tidak revisi \\
Praktis & 4 & $66-85$ & Sedikit revisi \\
Cukup praktis & 3 & $51-65$ & Sedikit revisi \\
Tidak praktis & 2 & $36-50$ & Revisi \\
Sangat tidak praktis & 1 & $20-35$ & Revisi \\
\hline
\end{tabular}

Keefektifan model pembelajaran diukur menggunakan tes uraian yang terdiri dari dua soal dengan empat pertanyaan. Sebelum digunakan, tes tersebut telah divalidasi oleh dosen pendidikan matematika dan dinyatakan layak untuk digunakan. Indikator tes meliputi: (a) mahasiswa mampu menyelesaikan masalah transportasi menggunakan metode barat laut; (b) mahasiswa mampu menyelesaikan masalah transportasi menggunakan metode Vogel; (c) mahasiswa mampu memahami penyelesaian masalah transportasi menggunakan metode biaya terendah, dan (c) mahasiswa mampu melakukan uji optimalitas. Keefektifan bahan ajar didapat dari standar kelulusan mata kuliah yaitu 61 atau terkategori $C$, sehingga Hasil Rating $(H R)$ untuk keefektifan model pembelajaran dihitung menggunakan rumus berikut.

$$
H R=\frac{\text { Jumlah mahasiswa yang mendapat nilai } \geq 61}{\text { Jumlah mahasiswa yang mengikuti tes }} \times 100 \%
$$

Selanjutnya, kategori tingkat keefektifan dan interpretasinya diukur berdasarkan Tabel 3. Model pembelajaran dinyatakan efektif jika HR berada pada kategori minimal "Efektif".

Tabel 3. Kategori keefektifan produk

\begin{tabular}{lcc}
\hline Penilaian & Skala nilai & Hasil rating $(\%)$ \\
\hline Sangat efektif & 5 & $86-100$ \\
Efektif & 4 & $66-85$ \\
Cukup efektif & 3 & $51-65$ \\
Tidak efektif & 2 & $36-50$ \\
Sangat tidak efektif & 1 & $20-35$ \\
\hline
\end{tabular}

HASIL PENELITIAN

\section{Tahap Pendefinisian (Define)}

Pada tahap ini ditetapkan dan didefinisikan kebutuhan perkuliahan program linear dengan menganalisis tujuan mata kuliah program linear. Tujuan mata kuliah adalah menerapkan konsep-konsep program linear dalam menyelesaikan masalah kehidupan sehari-hari yang berkaitan dengan pengambilan keputusan dan manajemen. Masalah kehidupan sehari-hari dalam hal ini adalah masalah transportasi yang tersaji dan harus diselesaikan oleh mahasiswa, berupa pengambilan keputusan dan manajemen masalah. Batasan materinya berdasarkan Kurikulum Program Studi Pendidikan Matematika IKIP PGRI Pontianak. Materi yang menjadi konteks dalam pengembangan produk ini adalah masalah transportasi dalam mata kuliah program linear.

Analisis awal-akhir dilakukan menentukan masalah dasar dari produk yang akan dikembangkan. Masalah dasar tersebut adalah pembelajaran yang dilaksanakan masih menonton serta penjelasan materi yang masih terpusat pada pengajar atau dosen. Dengan menelaah kurikulum dan teori belajar yang relevan, sehingga diperoleh deskripsi produk yang perlu dikembangkan berupa metode pembelajaran. Metode pembelajaran yang dianggap cocok untuk dikembangkan adalah metode halaqah berbasis etnomatematika.

Analisis mahasiswa dilakukan untuk menelaah karakteristik mahasiswa yang sesuai dengan rancangan pengembangan metode pembelajaran halaqah. Mata kuliah program linear terletak di semester IV yang memuat prosedur penyelesaian masalah. Mahasiswa matematika yang cenderung lemah dalam pemahaman prosedur yang terlihat pada hasil belajar mahasiswa angkatan sebelumnya, terutama pada materi penyelesaian masalah transportasi, dimana terdapat 13 mahasiswa yang belum memahami metode penyelesaian masalah transportasi hingga perkuliahan selesai pada akhir semester. Padahal permasalahan yang termuat dalam program linear merupakan masalah kehidupan sehari-hari yang harus dikuasai oleh mahasiswa saat berada di tengah-tengah masyarakat. 
Analisis konsep merupakan kegiatan mengidentifikasi, merinci, dan menyusun secara sistematis materi dan sumber bacaan yang dapat diintegrasi ke dalam pembelajaran. Mata kuliah yang menjadi objek dalam pengembangan metode ini adalah program linear. Konsep-konsep yang menjadi fokus dalam pengembangan ini meliputi definisi masalah transportasi dan metode penyelesaian masalah transportasi. Definisi masalah transportasi penting agar mahasiswa memiliki pemahaman konsep yang baik. Pemahaman konsep terkait masalah transportasi menjadi penting sebagai keterampilan dasar bagi mahasiswa untuk mengidentifikasi suatu permasalahan yang terkategori masalah transportasi atau bukan. Adapun untuk metode penyelesaian masalah transportasi, akan dibahas terkait metode barat laut, metode biaya terendah, dan metode Vogel. Selain itu, konsep berikutnya yang menjadi pertimbangan dalam pengembangan model pembelajaran adalah uji optimalitas yang menjelaskan teknik perhitungan untuk menguji keoptimalan dari penyelesaian yang diperoleh.

Analisis tugas dilakukan melalui pengkajian keterampilan yang menjadi fokus utama dalam mata kuliah program linear pada materi transportasi, yaitu mahasiswa memiliki keterampilan dalam menerapkan konsep program linear dalam menyelesaikan masalah kehidupan sehari-hari yang berkaitan dengan pengambilan keputusan dan manajemen, khususnya pada masalah transportasi. Metode pembelajaran yang digunakan adalah halaqah berbasis etnomatematika, sehingga dapat dirincikan keterampilan tambahan yang dapat diperoleh mahasiswa antara lain: 1) kemampuan berkolaborasi dan bekerja sama dalam menyelesaikan masalah; 2) kemampuan memahami karakter rekan belajar dalam menyelesaikan masalah; 3) kemampuan membimbing rekan belajar dalam menyelesaikan masalah; dan 4) kemampuan mengidentifikasi masalah etnik dan kegiatan masyarakat sebagai masalah program linear, khususnya yang berhubungan dengan transportasi.

Spesifikasi tujuan perkuliahan berdasarkan analisis yang dilakukan, berupa tujuan dari perkuliahan dengan metode pembelajaran halaqah berbasis etnomatematika, yaitu untuk memahamkan mahasiswa dalam menyelesaikan masalah transportasi pada kelas program linear. Penyelesaian masalah transportasi terdiri dari tiga metode yang harus dipahami oleh mahasiswa, sehingga tujuan perkuliahan dibagi ke dalam sub tujuan, yaitu: 1) mahasiswa harus memahami penyelesaian masalah transportasi menggunakan metode barat laut; 2) mahasiswa harus memahami penyelesaian masalah transportasi menggunakan metode biaya terendah; 3) mahasiswa harus memahami penyelesaian masalah transportasi menggunakan metode Vogel; dan 4) mahasiswa harus memahami prosedur pengujian optimalitas pada solusi masalah transportasi, agar mahasiswa dapat mengambil keputusan terhadap solusi yang telah diperoleh.

\section{Tahap Perancangan (Design)}

Berdasarkan hasil analisis pada tahap pendefinisian produk yang akan dikembangkan adalah metode pembelajaran. Metode pembelajaran yang dikembangkan adalah metode halaqah berbasis etnomatematika untuk memahamkan penyelesaian masalah transportasi pada mahasiswa yang mengikuti kelas program linear. Keberhasilan metode pembelajaran dilihat dari tes hasil belajar mahasiswa dalam menyelesaikan masalah terkait materi transportasi. Sintaks metode pembelajaran yang dikembangkan menyesuaikan model halaqah sebagai acuan. Rancangan awal metode pembelajaran halaqah berbasis etnomatematika disajikan pada Tabel 4 .

Fase dan langkah metode pembelajaran halaqah yang dikembangkan dalam penelitian ini merupakan modifikasi dari model pembelajaran halaqah Amirudin (Amirudin et al., 2018). Model halaqah yang digunakan dalam penelitian ini dinamakan Metode Halaqah Etnomatematika (MHE) yang merupakan transformasi dari Metode Halaqah Sederhana (MHS). Pada tahap 1, yaitu pemilihan kompetensi dan materi pada MHS, dapat diadopsi ke dalam MHE menjadi tahapan penentuan kompetensi dan materi yang berbasis etnomatematika, yaitu berupa biaya pendistribusian atau pembuatan baju tradisional Kopa Dayak Simpang Hulu. Pada tahap 2, pada MHS dilakukan pembentukan halaqah yang terdiri dari pengaturan posisi membentuk lingkaran dengan suasana kekeluargaan (Soleh et al., 2018), tahap ini dalam MHE dikembangkan dengan menambahkan pemilihan pembimbing kelompok dengan memilih mahasiswa yang berkemampuan tinggi dan ta'aruf atau perkenalan agar terjadi pemahaman karakter di antara peserta dan murobbi. Dalam kegiatan tersebut tiap-tiap anggota kelompok memperkenalkan diri dengan memaparkan karakternya masing-masing atau permasalahan yang dihadapi. Tahap 3 pada MHS berupa kegiatan pembelajaran yang terdiri dari pembukaan, tatap muka, diskusi, mutaba'ah (proses pembimbingan), penyampaian masalah dan berita gembira, pengumuman, dan kesimpulan. Kegiatan tahap 3 pada MHE dikembangkan dari MHS yaitu membuat aktivitas yang lebih spesifik, menyesuaikan dengan pembelajaran mata kuliah program linear khususnya materi masalah transportasi. Tahap 4 pada MHS terdiri dari silaturahmi yang bertujuan untuk mendekatkan diri antara peserta melalui kunjungan satu sama lain di luar pembelajaran, evaluasi untuk me- 
Tabel 4. Transformasi model halaqah sederhana menjadi metode halaqah etnomatematika

\begin{tabular}{|c|c|}
\hline Model halaqah sederhana & Metode halaqah berbasis etnomatematika \\
\hline Tahap 1: Pemilihan kompetensi dan materi & $\begin{array}{l}\text { Tahap 1: Pemilihan kompetensi dan materi berbasis } \\
\text { etnomatematika }\end{array}$ \\
\hline $\begin{array}{l}\text { Tahap 2: Pembentukan halaqah } \\
\text { a. Pengaturan posisi } \\
\text { b. Ta'aruf }\end{array}$ & $\begin{array}{l}\text { Tahap 2: Pembentukan halaqah } \\
\text { a. Pengaturan posisi } \\
\text { b. Memilih mahasiswa yang memiliki kemampuan } \\
\text { tinggi sebagai pembimbing kelompok } \\
\text { c. Ta'aruf }\end{array}$ \\
\hline
\end{tabular}

Tahap 3: Kegiatan pembelajaran

a. Pembukaan

b. Tatap muka

c. Diskusi

d. Mutaba'ah/membimbing

e. Penyampaian masalah dan berita gembira

f. Pengumuman

g. Kesimpulan
Tahap 3: Kegiatan pembelajaran

a. Pembukaan

b. Landasan ide pokok matematika: Identifikasi fakta dan permasalahan.

Contoh: Kebutuhan kulit kayu untuk pembuatan baju Kopa sebanyak 4 gulung, sedangkan hutan $A$ hanya punya tiga pohon Kopa dan hanya menghasilkan 2 gulung dengan biaya Rp75.000,00/batang dan hutan B memiliki lima pohon yang dapat menghasilkan 3 gulung dengan harga Rp90.000,00/batang. Bagaimanakah agar pembuatan baju Kopa menjadi efisien?

c. Membimbing mahasiswa yang memiliki kemampuan tinggi dalam bentuk kelompok

d. Mahasiswa yang memiliki kemampuan tinggi membimbing mahasiswa lainnya dalam bentuk kelompok

e. Menuliskan hasil identifikasi informasi penting

f. Diskusi dan memberikan argumentasi

g. Dosen membimbing dan mengontrol kelompok

h. Penyempurnaan penyelesaian masalah

i. Pengumuman

j. Kesimpulan

Tahap 4:

Tahap 4:

a. Silaturahmi

a. Silaturahmi

b. Evaluasi

b. Evaluasi

c. Persaudaraan

c. Persaudaraan

ngontrol pemahaman peserta di luar pembelajaran melalui tanya jawab singkat oleh pembimbing kelompok, dan persaudaraan yaitu membentuk komunitas kecil di luar pembelajaran untuk saling bantu membantu dalam pemahaman materi ajar.

\section{Tahap Pengembangan (Develop)}

Pada tahap ini dilakukan validasi oleh ahli pendidikan matematika dan uji coba metode pembelajaran halaqah berbasis etnomatematika untuk memahamkan penyelesaian masalah transportasi pada mahasiswa kelas program linear. Adapun hasil penilaian yang dilakukan oleh tiga validator, yaitu dosen pendidikan matematika, terhadap metode pembelajaran yang dikembangkan disajikan pada Tabel 5. Dari data pada Tabel 5 dapat disimpulkan bahwa penilaian metode pembelajaran yang dikembangkan dinyatakan valid. Dengan demikian, metode pembelajaran halaqah berbasis etnomatematika untuk memahamkan penyelesaian masalah transportasi pada mahasiswa kelas program linear layak untuk diujicobakan.

Uji coba metode pembelajaran halaqah berbasis etnomatematika untuk memahamkan penyelesaian masalah transportasi pada mahasiswa kelas program linear menyesuaikan kalender akademik dan program perku- 
liahan yang dilaksanakan di Program Studi Pendidikan Matematika IKIP PGRI Pontianak. Mahasiswa yang menjadi subjek pada saat uji coba adalah mahasiswa kelas A Sore semester IV tahun akademik 2019/2020. Untuk mengetahui kepraktisan metode pembelajaran mahasiswa dan dosen pengampu melakukan pengisian angket. Mahasiswa yang mengisi angket terdiri dari tiga orang, yaitu mahasiswa 1 merupakan perwakilan pembimbing kelompok, mahasiswa 2 merupakan perwakilan peserta laki-laki, dan mahasiswa 3 merupakan perwakilan peserta perempuan. Hasil penilaian kepraktisan oleh mahasiswa dan dosen pengampu terhadap metode pembelajaran yang dikembangkan disajikan pada Tabel 6. Dari data pada Tabel 6, dapat disimpulkan bahwa metode pembelajaran yang dikembangkan memenuhi kriteria kepraktisan. Hal tersebut menunjukkan metode pembelajaran halaqah berbasis etnomatematika layak digunakan dalam pembelajaran program linear.

Tabel 5. Hasil penilaian kevalidan metode pembelajaran

\begin{tabular}{lcl}
\hline Penilai & Hasil rating $(\%)$ & Keterangan \\
\hline Validator I & 77,33 & Valid \\
\hline Validator II & 76,67 & Valid \\
\hline Validator III & 79,33 & Valid \\
\hline Rata-rata & 77,78 & Valid \\
\hline
\end{tabular}

Tabel 6. Hasil penilaian kepraktisan metode pembelajaran

\begin{tabular}{lcl}
\hline Penilai & Hasil rating $(\%)$ & Kriteria \\
\hline Mahasiswa 1 & 94,54 & Sangat praktis \\
\hline Mahasiswa 2 & 96,36 & Sangat praktis \\
\hline Mahasiswa 3 & 92,72 & Sangat praktis \\
\hline Dosen pengampu & 94,67 & Sangat praktis \\
\hline
\end{tabular}

Keefektifan metode pembelajaran yang dikembangkan dinilai melalui data hasil tes. 31 mahasiswa mengikuti pembelajaran menggunakan metode pembelajaran halaqah berbasis etnomatematika pada materi penyelesaian masalah transportasi sebanyak tiga pertemuan. Setelah tiga kali pertemuan tersebut, mahasiswa diberikan tes yang memuat masalah transportasi. Hasil tes menunjukkan 29 orang memperoleh nilai melampaui atau sama dengan 60 , dan 2 orang gagal, sehingga diperoleh hitungan rasional sebagai berikut.

$\mathrm{HR}=\frac{\text { Jumlah siswa yang mendapat nilai } \geq 60}{\text { Jumlah Siswa yang mengikuti tes }} \times 100 \%$

$H R=\frac{29}{31} \times 100 \%=93,55 \%$

Berdasarkan Tabel 3, hasil penilaian sebesar 93,55\% berada pada kategori “Sangat Efektif”. Dengan demikian dapat disimpulkan bahwa metode pembelajaran halaqah berbasis etnomatematika efektif untuk memahamkan penyelesaian masalah transportasi pada mahasiswa kelas program linear.

\section{PEMBAHASAN}

Tujuan mata kuliah program linear di Program Studi Pendidikan Matematika, IKIP PGRI Pontianak yaitu agar mahasiswa mampu menerapkan konsep-konsep program linear dalam menyelesaikan masalah kehidupan seharihari yang berkaitan dengan pengambilan keputusan dan manajemen. Namun, faktanya pembelajaran yang dilaksanakan masih monoton, dimana penjelasan materi masih terpusat pada pengajar atau dosen. Oleh karena itu, diperlukan pengembangan metode pembelajaran sebagai bentuk inovasi dalam kegiatan perkuliahan. Inovasi dalam perkuliahan dapat berupa metode yang dianggap cocok atau relevan dengan kebutuhan penyelesaian masalah pembelajaran yang terjadi (Sani, 2013). Dalam penelitian ini, metode pembelajaran yang relevan dengan kondisi yang diamati adalah metode pembelajaran halaqah. Pembelajaran tersebut mengedepankan pemahaman bersama dalam kelompok-kelompok kecil dan penuh keakraban (Nashir \& Halib, 2017), karena tiap kelompok dibimbing oleh temannya sendiri.

Pada tahap pengembangan (develop) menunjukkan bahwa metode pembelajaran halaqah berbasis etnomatematika untuk memahamkan penyelesaian masalah transportasi pada mahasiswa kelas program linear terkategori dinyatakan valid oleh tiga ahli yang merupakan dosen pendidikan matematika. Metode pembelajaran yang 
dikembangkan juga memenuhi kriteria kepraktisan. Hal tersebut menunjukkan bahwa metode pembelajaran halaqah berbasis etnomatematika termasuk produk yang berkualitas, karena menurut Nieveen (Abidin, 2016) kepraktisan merupakan aspek yang perlu diperhatikan dalam menentukan kualitas suatu produk pengembangan. Metode pembelajaran halaqah berbasis etnomatematika juga efektif untuk memahamkan penyelesaian masalah transportasi pada mahasiswa kelas program linear. Nieveen (Abidin, 2016) mengemukakan bahwa kualitas dari produk pengembangan harus memenuhi tiga aspek yaitu valid, praktis, dan efektif. Dengan demikian, metode pembelajaran halaqah berbasis etnomatematika yang dikembangkan memiliki kualitas yang baik, sehingga dapat dijadikan sebagai alternatif untuk mengajarkan materi yang berbeda atau pada mata kuliah lain yang berhubungan dengan matematika. Selain itu, proses pengembangan yang dilakukan juga dapat menjadi rujukan bagi peneliti pendidikan matematika untuk mengembangkan suatu metode pembelajaran.

Keterbatasan dalam penelitian ini adalah mahasiswa pendidikan matematika yang berasal dari beraneka ragam etnik, sehingga harus dikenalkan terlebih dahulu mengenai konteks etnomatematika yang digunakan. Selain itu, salah satu langkah metode halaqah adalah pembelajaran yang terjadi di luar kelas, sehingga di masa yang akan datang masing-masing kelompok perlu dibekali lembar catatan dan lembar observasi selama kegiatan pembelajaran di luar kelas dan waktu pelaksanaannya yang terjadwal. Selain itu, uji coba metode pembelajaran masih dilaksanakan pada skala kecil, sehingga belum ada jaminan bahwa metode pembelajaran akan efektif jika diterapkan pada subjek lainnya. Untuk itu, diperlukan uji coba pada skala yang lebih luas untuk menguji efektivitas model pembelajaran, serta mendapatkan masukan-masukan lainnya untuk penyempurnaan metode pembelajaran yang dikembangkan.

\section{SIMPULAN}

Penelitian dan pengembangan ini menghasilkan metode pembelajaran halaqah berbasis etnomatematika untuk memahamkan materi penyelesaian masalah transportasi pada mahasiswa kelas program linear. Berdasarkan penilaian ahli, metode pembelajaran yang dikembangkan dinilai valid. Berdasarkan penilaian dosen dan mahasiswa, metode pembelajaran yang dikembangkan juga memenuhi kriteria kepraktisan. Selain itu, berdasarkan hasil tes setelah pembelajaran menggunakan metode yang dikembangkan, dapat disimpulkan bahwa metode pembelajaran efektif untuk memahamkan materi penyelesaian masalah transportasi pada mahasiswa kelas program linear. Dengan demikian, metode pembelajaran halaqah berbasis etnomatematika untuk memahamkan materi penyelesaian masalah transportasi pada mahasiswa kelas program linear dinyatakan layak digunakan dan dapat diujicobakan pada skala yang lebih besar. Selain itu, metode pembelajaran halaqah juga dapat digunakan pada materi matematika yang lain dengan menggunakan konteks etnomatematika atau pun tidak. Selain itu, untuk penelitian selanjutnya dapat difokuskan pada pengembangan media atau perangkat pembelajaran dengan menggunakan metode halaqah.

\section{UCAPAN TERIMA KASIH}

Ucapan terima kasih kami tujukan kepada Direktorat Riset dan Pengabdian pada Masyarakat (DRPM) Kemenristek/BRIN Republik Indonesia yang telah menjadi sponsor dalam pendanaan pelaksanaan penelitian ini. Selain itu, ucapan terima kasih ditujukan kepada IKIP PGRI Pontianak yang memfasilitasi kegiatan penelitian ini dan izin pelaksanaan yang diberikan, serta tim penilai, subjek penelitian, dan tim administrasi yang membantu.

\section{DAFTAR PUSTAKA}

Abi, A. M. (2017). Integrasi etnomatematika dalam kurikulum matematika sekolah. JPMI (Jurnal Pendidikan Matematika Indonesia), 1(1), 1-6. https://doi.org/10.26737/jpmi.v1i1.75

Abidin, Z. (2016). Pengembangan model pembelajaran matematika berbasis portofolio (PMBP) pada siswa sekolah menengah pertama. Jurnal Pendidikan Matematika, 2(1), 79-102. http://dx.doi.org/10.33474/jpm.v2i1.209

Agustina, L. (2016). Upaya meningkatkan kemampuan pemahaman konsep dan pemecahan masalah matematika siswa SMP Negeri 4 Sipirok kelas VII melalui pendekatan matematika realistik (PMR). Eksakta: Jurnal Penelitian dan Pembelajaran MIPA, 1(1), 1-12. http://dx.doi.org/10.31604/eksakta.v1i1.\%25p

Amirudin, A., Munda, S. N., Saemina, S., \& Alwi, W. O. M. (2018). Meningkatkan kemampuan menulis teks eksplanasi melalui penerapan pembelajaran model halaqah pada siswa kelas VIII SMPN 15 Kendari. 
Prosiding Seminar Nasional Hibah Program Penugasan Dosen Ke Sekolah, pp. 27-32. http://pdsunp.ppj.unp.ac.id/index.php/PDSUNP/article/view/5

Dalimunthe, A. Y. (2019). Halaqah dan munazharah warisan pendidikan islam klasik. Forum Paedagogik, 11(1), 1526. http://jurnal.iain-padangsidimpuan.ac.id/index.php/JP/article/view/1775/1529

Haran, A., Hartoyo, A., \& Sayu, S. (2019). Etnomatematika dalam merangkai manik masyarakat Dayak Kayaan Kapuas Hulu. Jurnal Pendidikan dan Pembelajaran, 8(3), 1-8. https://jurnal.untan.ac.id/index.php/jpdpb/article/view/31952

Hariastuti, R. M. (2017). Permainan tebak-tebak buah manggis: Sebuah inovasi pembelajaran matematika berbasis etnomatematika. JMPM: Jurnal Matematika dan Pendidikan Matematika, 2(1), 25-35. https://doi.org/10.26594/jmpm.v2i1.776

Hartono, H., \& Saputro, M. (2019). Ethnomathematics on Dayak tabun traditional tools for school mathematics learning. International Journal of Trends in Mathematics Education Research, 1(3), 80-86. https://doi.org/10.33122/ijtmer.v1i3.24

Hartoyo, A. (2012). Eksplorasi etnomatematika pada budaya masyarakat Dayak perbatasan Indonesia-Malaysia Kabupaten Sanggau Kalbar. Jurnal Penelitian Pendidikan, 13(1), 14-23.

Hasanah, S. I., Hafsi, A. R., \& Zayyadi, M. (2019). Pengembangan lembar kerja siswa berbasis etnomatematika dalam membangun pemahaman konsep siswa. Jurnal Pendidikan Matematika dan IPA, 10(2), 183-191. https://doi.org/10.26418/jpmipa.v10i2.29609

Junaidi, K. (2016). Sistem pendidikan pondok pesantren di Indonesia (suatu kajian sistem kurikulum di Pondok Pesantren Lirboyo). Istawa: Jurnal Pendidikan Islam, 2(2), 95-110.

Kumalasari, A., \& Sugiman, S. (2015). Analisis kesulitan belajar mahasiswa pada mata kuliah kapita selekta matematika sekolah menengah. Jurnal Riset Pendidikan Matematika, 2(1), 16-27. https://doi.org/10.21831/jrpm.v2i1.7147

Mardiah, S., Widyastuti, R., \& Rinaldi, A. (2018). Pengembangan modul pembelajaran matematika berbasis etnomatematika menggunakan metode inkuiri. Desimal: Jurnal Matematika, 1(2), 119-126. https://doi.org/10.24042/djm.v1i2.2228

Muchtadi, M., Hartono, H., \& Oktaviana, D. (2017). Hubungan aktivitas dan respon terhadap hasil belajar program linier setelah diterapkan pembelajaran genius learning pada program studi pendidikan matematika. Edu Sains: Jurnal Pendidikan Sains \& Matematika, 5(1), 45-55. https://doi.org/10.23971/eds.v5i1.668

Mujizatullah, M. (2018). Metode pengajian kitab pada Pondok Pesantren Salafiyah Darul Muttaqin Mannanti Kabupaten Sinjai. Al-Maraji': Jurnal Pendidikan Bahasa Arab, 4(2), 1-10. https://journal.unismuh.ac.id/index.php/al-maraji/article/view/3643

Munawwir, A. W. (1997). Kamus al-munawwir Arab-Indonesia. Pustaka Progresif.

Muslimin, A. (2016). Implementasi metode halaqah dan resitasi dalam tahfidz Al-Quran di SDIT El - Haq Banjarsari Buduran Sidoarjo. Adabiyah: Jurnal Pendidikan Islam, 1(1), 55-62. https://doi.org/10.21070/ja.v1i1.164

Nashir, A., \& Halib, A. (2017). Sistem pembinaan halaqah terhadap kecerdasan emosional santri di markaz tahfidz Alquran Al-Birr. Jurnal Tarbawi, 1(2), 85-93. https://doi.org/10.26618/jtw.v1i2.361

Octaria, D., \& Puspasari, E. F. (2018). Peningkatan self-efficacy mahasiswa melalui problem based learning (PBL) pada mata kuliah program linier. Jurnal Elemen, 4(1), 66-79. https://doi.org/10.29408/jel.v4i1.496

Oktaviana, D. (2018). Analisis tipe kesalahan berdasarkan teori Newman dalam menyelesaikan soal cerita pada mata kuliah matematika diskrit. Edu Sains: Jurnal Pendidikan Sains \& Matematika, 5(2), $22-32$. https://doi.org/10.23971/eds.v5i2.719

Puspadewi, K. R., \& Putra, I. G. N. N. (2014). Etnomatematika di balik kerajinan anyaman Bali. Jurnal Matematika, 4(2), 80-89. https://doi.org/10.24843/JMAT.2014.v04.i02.p47 
Putri, L. (2017). Eksplorasi etnomatematika kesenian rebana sebagai sumber belajar matematika pada jenjang MI. Jurnal IImiah Pendidikan Dasar Unissula, 4(1), 21-31. http://dx.doi.org/10.30659/pendas.4.1.\%25p

Sani, R. A. (2013). Inovasi pembelajaran. Bumi Aksara.

Sari, I. P., Purwasih, R., \& Nurjaman, A. (2017). Analisis hambatan belajar mahasiswa pada mata kuliah program linear. JIPM (Jurnal Ilmiah Pendidikan Matematika), 6(1), 39-46. https://doi.org/10.25273/jipm.v6i1.1569

Soleh, A., Maya, R., \& Priyatna, M. (2018). Metode halaqah dalam pembelajaran tahfidz Al-quran di Pondok Pesantren Tahfidz Alquran Darussunnah Parung Kabupaten Bogor tahun 2018. Prosiding Al Hidayah Pendidikan Agama Islam, pp. 43-52. http://dx.doi.org/10.30868/ppai.v1i2.408

Sulianto, J. (2008). Pendekatan kontekstual dalam pembelajaran matematika untuk meningkatkan berpikir kritis pada siswa sekolah dasar. Pythagoras: Jurnal Pendidikan Matematika, 4(2), 14-25. https://doi.org/10.21831/pg.v4i2.555

Tanjungsari, R. D., Soedjoko, E., \& Mashuri, M. (2012). Diagnosis kesulitan belajar matematika SMP pada materi persamaan garis lurus. Unnes Journal of Mathematics Education, 1(1), 52-57. https://doi.org/10.15294/ujme.v1i1.261

Thiagarajan, S., Semmel, D. S., \& Semmel, M. I. (1974). Instructional development for training teachers of exceptional children. Indiana University.

Umam, A. B., Alimron, A., \& Sukirman, S. (2020). Pelaksanaan model halaqah pendidikan agama islam di Surau Kelurahan 13 Ulu Palembang. Jurnal PAI Raden Fatah, 2(3), 309-319. https://doi.org/10.19109/pairf.v2i3.5552

Yudhaskara, H., \& Tjahyaningtyas, R. (2016). Pengembangan media pembelajaran berbasis flash pada standar kompetensi melakukan instalasi sofware di SMK Gama Kedungadem Bojonegoro. Jurnal Pendidikan Tehnik Elektro, 5(3), 891-896. https://jurnalmahasiswa.unesa.ac.id/index.php/jurnal-pendidikan-teknikelektro/article/view/16481 